IZA DP No. 9112

Do the Unemployed Accept Jobs Too Quickly?

A Comparison with Employed Job Seekers

Simonetta Longhi

June 2015 


\title{
Do the Unemployed Accept Jobs Too Quickly? A Comparison with Employed Job Seekers
}

\author{
Simonetta Longhi \\ ISER, University of Essex \\ and IZA
}

\author{
Discussion Paper No. 9112 \\ June 2015
}

\author{
IZA \\ P.O. Box 7240 \\ 53072 Bonn \\ Germany \\ Phone: +49-228-3894-0 \\ Fax: +49-228-3894-180 \\ E-mail: iza@iza.org
}

\begin{abstract}
Any opinions expressed here are those of the author(s) and not those of IZA. Research published in this series may include views on policy, but the institute itself takes no institutional policy positions. The IZA research network is committed to the IZA Guiding Principles of Research Integrity.

The Institute for the Study of Labor (IZA) in Bonn is a local and virtual international research center and a place of communication between science, politics and business. IZA is an independent nonprofit organization supported by Deutsche Post Foundation. The center is associated with the University of Bonn and offers a stimulating research environment through its international network, workshops and conferences, data service, project support, research visits and doctoral program. IZA engages in (i) original and internationally competitive research in all fields of labor economics, (ii) development of policy concepts, and (iii) dissemination of research results and concepts to the interested public.
\end{abstract}

IZA Discussion Papers often represent preliminary work and are circulated to encourage discussion. Citation of such a paper should account for its provisional character. A revised version may be available directly from the author. 


\section{ABSTRACT}

\section{Do the Unemployed Accept Jobs Too Quickly? A Comparison with Employed Job Seekers}

This paper analyses differences between unemployed and employed job seekers in job finding rates and in the quality of the job found. Compared to the unemployed, employed job seekers have a smaller pool of job offers that they consider acceptable; this leads to lower job finding rates but better quality jobs. Differences in job quality are tiny when unobserved heterogeneity and selection into accepting a job are accounted for. Hence, differences are mostly due to behaviour of unemployed people rather than negative signaling or employer discrimination.

JEL Classification: J01, J20, J29, J62, J64

Keywords: on-the-job search, unemployment, job-finding rate, job quality

Corresponding author:

Simonetta Longhi

ISER

University of Essex

Wivenhoe Park

Colchester, CO4 3SQ

United Kingdom

E-mail: slonghi@essex.ac.uk

\footnotetext{
* I would like to thank Mark Taylor for extensive discussions on an earlier version of this paper. I would also like to thank participants at the Joint Empirical Social Science Seminars at the University of Essex (February 2011, January 2015), and the Conference of the Scottish Economic Society (April 2011), for helpful comments. This paper forms part of the project "Job search in the UK 1990-2006", funded by the Leverhulme Trust Grant no. F/00 213/O; it also forms part of a programme of research funded by the Economic and Social Research Council through their grant to the Research Centre on Micro-social Change in ISER. The support provided by the ESRC and the University of Essex is gratefully acknowledged. LFS data are available from the Data Archive at the University of Essex (http://discover.ukdataservice.ac.uk/series/?sn=2000026, see GN 33246).
} 


\section{Introduction}

The literature suggests that reductions in unemployment (or welfare) benefits increase the transition rates from unemployment into employment; there is no consensus, however, on whether the shorter search results in worse jobs (Nekoei and Weber 2015). From a policy point of view, the quicker unemployed people find new jobs, the sooner they stop claiming unemployment benefit and start paying income taxes. However, this may have hidden costs as the unemployed tend to find jobs that pay comparatively lower wages (Arulampalam 2001; Gregg and Tominey 2005) and are likely to be unstable (Böheim and Taylor 2002; Booth et al. 2002). Unemployed entering lower quality jobs will pay comparatively lower income tax and will be at a higher risk of further unemployment; this may have long-lasting consequences for welfare and for individuals.

Recent research on recipients of unemployment benefits in Germany suggests that longer durations of unemployment benefits translate into jobs that last longer and pay higher wages (Caliendo et al. 2013). For Sweden, van den Berg and Vikström (2014) find that punitive sanctions related to refusal of suitable job offers lead to higher transitions into jobs, but also more transitions into lower quality jobs.

Instead of focusing on recipients of unemployment benefits, this paper contributes to the debate on the trade-off between shorter unemployment spells and larger scars from unemployment by comparing unemployed job seekers (whether receiving unemployment benefits or not) to job seekers who are employed. The comparison includes job finding rates and various job characteristics such as wages, hours, and permanency. By accounting for unobserved individual heterogeneity and selection into accepting a job offer this paper also explores the additional impact of negative signalling on the re-employment of unemployed people and therefore also contributes to the literature on unemployment scarring (e.g. Arulampalam 2001; Arulampalam et al. 2001). The paper also contributes to the literature comparing job search outcomes of (successful) unemployed and employed job seekers (e.g. Blau and Robins 1990; Weber and Mahringer 2008). This literature generally focuses on successful job seekers and cannot control for self-selection in job offer acceptance.

Theoretical models of job search predict that employed job seekers will find better jobs than unemployed job seekers (Pissarides 1994; see also Rogerson et al. 2005 for a review) although predictions on the probability of finding a jobs are not clear-cut. From the supply side, the unemployed tend to have worse observed characteristics than job seekers who are employed and they may be more willing than employed job seekers to accept any job 
to avoid the stigma of unemployment or because of low financial means, or unemployment benefit duration or sanctions. From the demand side, if employers interpret unemployment as a negative signal, the worse re-employment outcomes for the unemployed may be the result of constraints or inefficiencies in the labour market and may be independent on the behaviour of unemployed job seekers.

In terms of the probability of finding a job, the signalling theory suggests that employers will prefer employed job applicants to unemployed ones (Blanchard and Diamond 1994, Eriksson and Gottfries 2005; Eriksson and Lagerstrom 2006) thus reducing the probability of finding a job for the unemployed. If the negative signal is relevant and unemployed people are channelled into a secondary labour market, the outcome of their job search is somehow constrained and independent on their behaviours and choices. We would expect the unemployed to be less likely to find a job and to find lower quality jobs. On the other hand, it is possible that some unemployed find comparatively worse jobs because they feel pressure to quickly find a job and are therefore prepared to accept job offers that they would not have accepted had they had a job. If this is the case, we would expect the unemployed to find jobs more quickly than employed job seekers, but also to find worse jobs on average. However, we should expect no differences in job quality after controlling for self-selection into accepting a job offer.

The results suggest that the difference between employed and unemployed job seekers is consistent with employed and unemployed job seekers having different reservation wages and different expectations about other job characteristics such as permanency and working hours. In contrast to the predictions of the signalling theory, the unemployed have a higher probability of receiving an acceptable job offer than employed job seekers, and this difference remains after controlling for observed worker and spouse's characteristics, job search behaviour, and unobserved individual heterogeneity. Controlling for differential selection into a new job, the results also suggest that employed job seekers accept jobs with higher wages than the unemployed, and are more likely than the unemployed to find permanent jobs that meet their working hour requirements. However, although systematic, these differences are tiny and suggest that that both types of jobs seekers operate in the same labour market and the impact of signalling (i.e. employer behaviour) is less relevant than the impact of behaviour (i.e. accepting any job) in determining the quality of the job found. The pressure that unemployed people may feel to accept any job may have a positive impact on their probability of finding a job, but may also have negative consequences on the quality of the job found and on their subsequent (employment) careers. 


\section{Theoretical background and modelling strategy}

\subsection{The job search model}

The most appropriate theoretical background for the comparison of employed and unemployed job seekers is the job search model. The model presented here is commonly used in the literature and is derived from Rogerson et al. (2005).

Consider a labour market with two types of job seekers: unemployed and employed people engaging in on-the-job search. Employed people who do not engage in on-the-job search are excluded. Job seekers maximise their lifetime utility, which is a function of the expected income received when employed and when unemployed $\left(\mathrm{I}_{t}\right)$, in a stationary environment. In the discrete case:

$$
\text { Utility }=\max \left[E\left(\sum_{t=0}^{\infty} \beta^{t} \mathrm{I}_{t}\right)\right]
$$

Where $E$ refers to the expected value, $\beta$ is a discount factor ranging from zero to one, and $\mathrm{I}_{t}$ is income. When the job seeker is employed, his income is $w$. It is common to proxy income by wages; however, we could interpret $w$ as a bundle of job characteristics including not only wages, but also characteristics such as job security, autonomy, and so on. Income from employment is then a measure of the desirability of the job (see also Rogerson et al. 2005). When the job seeker is unemployed his income is $b$ and may include unemployment benefits, the utility of additional leisure or of home production, and so on.

At each point in time each employed and unemployed job seeker randomly draws a job offer with job desirability $w$ from a known i.i.d. distribution of job offers $F(w)$, and decide whether to accept the offer or not. If the offer is rejected, the job seeker does not change status (e.g. employed or unemployed) and keeps searching. Even though all job offers are acceptable by at least one job seeker, because of search frictions, and because $w$ is a bundle of job characteristics, even unemployed job seekers may find a subset of job offers unacceptable. When the job offer is rejected, no match is produced and the job offer goes back into the pool of offers. When the offer is accepted the job seeker enters the job and may either stop searching, or still participate in the search process and evaluate new offers (although search intensity may change). 
In the continuous case we can set $\beta=1 /(1+r \Delta)$, where $\Delta$ is the length of the period. New job offers arrive at rate $\alpha_{0}$ while unemployed, and at rate $\alpha_{1}$ while employed, and $\lambda$ is the exogenous rate of job loss (see Rogerson et al. 2005). When $\Delta \rightarrow 0$ :

$$
r U=b+\alpha_{0} \int_{w_{R}}^{\infty}[W(w)-U] d F(w)
$$

and

$$
r W(w)=w+\alpha_{1} \int_{0}^{\infty} \max \left\{W\left(w^{\prime}\right)-W(w), 0\right\} d F\left(w^{\prime}\right)+\lambda[U-W(w)]
$$

$U$ and $W(w)$ are the values of being unemployed and employed, while $r U$ and $r W(w)$ are the flow value per period. These flow values are the sum of the instantaneous payoff ( $b$ for the unemployed and $w$ for the employed) and the expected value of any changes in the job seeker's state. The second term in equation (2) is the expected increase in income from a move into a job $(W(w)-U)$ multiplied by the probability that the unemployed receives a job offer $\left(\alpha_{0}\right)$ and represents the event in which the unemployed receives a job offer higher than his "reservation desirability" (i.e. including reservation wage and all other job characteristics). The second term in equation (3) is the event in which the employed job seeker receives a job offer $\left(W\left(w^{\prime}\right)\right)$ higher than his current job desirability, while the third term refers to a job loss. From equations (2) and (3) the unemployed have a reservation desirability such that $W\left(w_{R}\right)=U$ and employed job seekers switch jobs when $w^{\prime}>w$ (see Rogerson et al. 2005). Compared to employed job seekers, unemployed people are likely to consider "acceptable" a larger proportion of job offers (Gruetter and Lalive 2009).

\subsection{Probability of finding a job}

The job search model implies that the probability that the job seeker has not found a job after a spell of length $e^{-h t}$ is $H=\alpha\left[1-F\left(w_{R}\right)\right]$ and is the product of the job offer arrival rate $\left(\alpha: \alpha_{0}\right.$ for the unemployed and $\alpha_{1}$ for employed job seekers) and the probability of accepting the job offer $1-F\left(w_{R}\right)$, where $w_{R}$ is the reservation desirability for the unemployed and the current job desirability for employed job seekers. Whether the probability of finding a job is higher for employed or unemployed job seekers is still an open question.

Empirically, the job offer arrival rate is not observable, and may differ depending on individual characteristics and behaviours. What we observe is the pool of jobs accepted by employed and unemployed job seekers. The estimated probability that the job seeker accepts a job offer is a function of his individual characteristics and behaviours, and the acceptability 
of the offer given his current situation. If both unemployed and employed job seekers draw job offers from the same distribution and unemployment is not interpreted as a negative signal by employers, the (unobserved) probability of being offered a job should be the same for both job seekers after controlling for those characteristics that generate heterogeneity in the job offer arrival rate. The (unobserved) quality of jobs offered should also be the same on average, while the probability of finding any offer acceptable may be higher for the unemployed, thus generating a higher probability of finding a job for the unemployed. ${ }^{1}$ If, on the other hand, employers use unemployment as a signal of low productivity and rank job applicants on the basis of such signals, we should instead observe a lower probability of finding a job for unemployed job seekers since the unemployed would be offered the job only if there were no employed job applicants, or all employed job applicants rejected the job offer. In this case we should also observe a lower average quality of the jobs offered to the unemployed.

The dataset used in this paper allows us to control for most of the individual characteristics and behaviours that may result in differences among job offer arrival rates, including unobserved heterogeneity. Hence, conditional on these characteristics, we can assume that the job offer arrival rate is the same for employed and unemployed job seekers. The probability of accepting a job offer can be operationalised using a correlated random effect probit model.

Since we only observe job characteristics for those who accept a job offer, it is not possible to include the characteristics of the job (accepted) among the explanatory variables. The quality of the job accepted by employed and unemployed job seekers is analysed in a separate step.

\subsection{Quality of the job found}

Although the reservation desirability is likely to be higher for employed job seekers than for the unemployed, it is unclear how the different characteristics of the job sum up to the overall desirability, and whether the unemployed weight each characteristic differently than employed job seekers (Bonhomme and Jolivet 2009, Sullivan and To 2014). For example, because of financial constraint the unemployed may be less willing (than employed job seekers) to trade-off wages for other job characteristics. The aim of the second part of the

\footnotetext{
${ }^{1}$ Gush et al. (2015) provide qualitative evidence that unemployed people are likely to accept the first job that may come along.
} 
analysis is to compare how the characteristics of the job accepted by an employed job seeker differ from the characteristics of the job accepted by the unemployed.

If signalling is important and unemployed job seekers are channelled into a secondary labour market, we would expect significant differences in the quality of the job accepted by the two types of job seekers. However, if differences are mostly due to different behaviours and in the pressure to find a job, we should expect no differences between unemployed and employed job seekers once we account for the observed and unobserved characteristics that have an impact on the probability of finding a job.

A convenient way to compare the quality of the job accepted by employed and unemployed job seekers is to estimate a model in which the dependent variable is a dummy for whether the person hired in the job was an unemployed job seeker as opposed to an employed job seeker. The explanatory variables are the various characteristics of the job. This allows us to use a probit Heckman selection model to account for selection into accepting a job offer.

In summary, if the main reason why the unemployed find bad quality jobs is due to negative signals and labour market constraints we would expect the unemployed to have lower job finding rates and to find lower quality jobs than employed job seekers. If the main reason why the unemployed find bad quality jobs is due to the higher probability of unemployed people accepting any job offer, we would expect them to have higher job finding rates than employed job seekers. Although on average we may still observe differences in job quality, we would expect both unemployed and employed job seekers to find similar quality jobs once we control for characteristics and self-selection into accepting a job offer.

\section{Data and descriptive statistics}

The analysis is based on the UK quarterly Labour Force Survey (LFS). The LFS is a representative survey of households living in the UK which collects data quarterly on a large number of individual and household characteristics. The analysis uses data from 1993, when information on wages became available, up to the first quarter of 2010, and excludes Northern Ireland. ${ }^{2}$

\footnotetext{
${ }^{2}$ The quarterly nature of the data means that search spells that take place between two interviews are not recorded. The data capture some of these short spells, when an interview happens during that spell. The analysis relies on the assumption that short search spells are not systematically different than longer ones once we control for both observed and unobserved characteristics.
} 
The LFS has two important features: it asks questions on job search to both employed and unemployed respondents, and has a rotating panel structure where people are interviewed for up to five successive quarters. This allows a direct comparison between the unemployed and employed people engaging in on-the-job search, it allows the identification of job seekers who find a (new) job by the following quarter and the characteristics of the job found. Although the panel dimension is relatively short, it also allows to control for individual unobserved heterogenetiy.

For the purpose of this analysis job seekers as respondents who: (1) are looking for paid employment; (2) have looked for work in the last four weeks; and (3) mention at least one method of job search. To avoid complications related to the complexity of female labour market attachment, the focus here is on men who are either employed or unemployed and who actively search for a job. While almost all unemployed search for a job, about $5-6 \%$ of those who are employed engage in on-the-job search (see Longhi and Taylor 2014 for more details). Hence, the number of job seekers in the labour market is roughly equally split between the unemployed and those who search on-the-job.

Table 1 presents summary statistics by job seeker status. Employed and unemployed job seekers differ in terms of the intensity of job search, with unemployed job seekers on average using almost 5 and employed job seekers using about 3 different search methods (this is consistent with what Kuhn and Mansour 2014 find for the US). Higher search intensity for the unemployed is consistent with a greater pressure to find a job. The unemployed are more likely than employed job seekers to use job centres or private career offices, while employed job seekers are more likely to respond to newspaper advertisements. Most employed job seekers search because various aspects of their job (from wages to commuting time) are considered to be unsatisfactory, while about $14.3 \%$ look for a job because their current job may soon come to an end.

\section{TABLE 1 ABOUT HERE}

Compared to employed job seekers, on average the unemployed have lower levels of education, are less likely to have children and to have a spouse. Unemployed job seekers' spouses are less likely to have a job (either a paid job or self-employment) and are paid lower wages than spouses of job seekers who are employed, but there seem to be no difference in part-time or temporary jobs. 
The bottom rows of Table 1 summarise the job search outcomes. ${ }^{3}$ On average, $7.2 \%$ of unemployed people find a job by the following quarter (this includes people with any length of search), compared with $6.6 \%$ of employed job seekers. The quality of the jobs found by unemployed and employed job seekers differ considerably. The average hourly wages in the jobs found by the unemployed are $£ 7.70$ compared with $£ 9.66$ for employed job seekers; $32.1 \%$ of unemployed job seekers enter a temporary job, compared to $19.8 \%$ of employed job seekers.

The LFS asks job seekers whether they are looking for a full-time job, a part-time job, or are indifferent between the two. A variable can be defined that takes the value one for those job seekers who accepted a part-time (full-time) job and were looking for a part-time (full-time) job or were indifferent between the two. In case of a mismatch the variable takes the value zero. Table 1 shows that $91.0 \%$ of unemployed job seekers accepted a job offer with the sought working hours compared with $95.2 \%$ of employed job seekers. However a larger proportion of unemployed than employed job seekers is indifferent between part- and full-time jobs and so will not be classified as mismatched. Hence, differences are likely to be larger than appears from this analysis.

\section{Econometric models}

\subsection{Probability of finding a job}

We can compare the probability of employed and unemployed job seekers finding a job using a correlated random effects probit model. The dependent variable is binary, taking the value one if a worker finds a job by the following quarter, and zero otherwise. This is observed at most at four quarterly interview dates. The model for individual $i$ is specified as follows:

$$
Y_{i t}^{*}=X_{i t-1}^{\prime} \beta_{Y}+S_{i t-1}^{\prime} \theta_{Y}+J_{i t-1}^{\prime} \delta_{Y}+\alpha_{i}+\varepsilon_{i t}
$$

\footnotetext{
${ }^{3}$ In the LFS information on wages are collected only in the fifth interview from 1993 and both in the first and fifth interview since 1997. To increase sample size, wage data for the second, third, and fourth interviews are imputed under the assumption that wages do not change significantly within five quarters. If there has been a job change in the period considered, wage data collected from the first interview (if available) are imputed to all quarters before the job change, and wage data collected from the fifth interview are imputed to all quarters after the job change. Since this may include measurement error, some of the models have been re-estimated excluding wages that have been imputed. Similarly, information on unions, days off and commuting time have been collected at (sometimes irregular) intervals, and are generally available only since 2003-2004. To increase sample size, missing observations are imputed for those waves where the current job is the same as the job when such data were collected. As sensitivity analyses, models are estimated including and excluding these variables.
} 
Where $Y_{i t}^{*}$ is the unobservable individual propensity to have entered a job at time $t, X_{i t-1}^{\prime}$ is a vector of individual characteristics affecting $Y_{i t}^{*}, J_{i t-1}^{\prime}$ is a vector of search-related characteristics, $S_{i t-1}^{\prime}$ is a binary variable indicating whether the job seeker was employed rather than unemployed, $\alpha_{i}$ captures the individual unobserved heterogeneity, and $\varepsilon_{i t}$ is the unobservable error term. $\beta_{Y}, \theta_{Y}$ and $\delta_{Y}$ are parameters to be estimated. All explanatory variables refer to the time of the search $(t-1)$ rather than the time of entry into the job $(t)$.

An individual is observed entering a job when his propensity to enter a job exceeds zero. If $\varepsilon_{i t} \sim \operatorname{IN}\left(0, \sigma_{\varepsilon}^{2}\right)$ we can use a correlated random effect probit model that includes among the explanatory variables the individual mean of all time-varying covariates to partly control for possible correlation between the individual unobserved heterogeneity $\left(\alpha_{i}\right)$ and the explanatory variables (Mundlak 1978; Wooldridge 2010). A positive estimate for $\theta_{Y}$ indicates that employed job seekers are more likely than otherwise similar unemployed job seekers to accept a job offer.

The vector of individual characteristics $X_{i t-1}^{\prime}$ includes age, dummies for highest education level, for the presence of children younger than 18 and for employment characteristics of the spouse (if any); these include a dummy for whether in the data we have information about the spouse, a dummy for whether the spouse has a job (paid job or selfemployment), dummies for whether her job is temporary or part-time, and her hourly wages (only for those with a paid job). These variables are all set to zero for those who do not have a spouse. Whether the partner has a job, and the characteristics of her job are likely to have an impact on the pressure to find a job, with an indirect impact on the pool of job offers that the job seeker may consider acceptable. It is likely that having a partner with a (good) job will result in a narrower pool of job offers that the job seeker will consider acceptable. $X_{i t-1}^{\prime}$ also includes dummies for the nine English Government Office Regions, plus Wales and Scotland, together with dummies for year and quarter of the survey, and a dummy for the years of the recent recession (2008-onwards).

The vector of search-related characteristics $\left(J_{i t-1}^{\prime}\right)$ includes the number of search methods used (to proxy for search intensity), dummies for the main job search method used and length of job search (or unemployment duration). For those who are employed job seekers $J_{i t-1}^{\prime}$ also includes dummies for the main reason of job search, with unemployed used as reference group.

It is also important to ascertain whether the returns to individual characteristics, job search methods, length of search, and labour market conditions differ for employed and 
unemployed job seekers. For example, we might expect particular types of job search methods to be more effective for employed job seekers and others to be more effective for the unemployed. Hence, the probability that the job seeker finds a job is also modelled separately for unemployed and employed job seekers.

\subsection{Quality of the job found}

The second research question relates to the quality of the job found conditional on finding a job and focuses on how jobs filled by employed job seekers compare with those filled by the unemployed. The data include various measures of job quality: wages, contractual status (temporary/fixed term or permanent), whether or not the job found corresponds to the stated job search criteria in terms of working hours, presence of unions at the workplace, the number of days off per year and commuting time. It is likely that job seekers will jointly evaluate all the characteristics of the job before deciding whether to accept or reject a job offer.

Estimating a system of equations in which each job characteristic is used as dependent variable would not easily allow to model selection into accepting a job. Since neglecting non-random selection may cause biased estimates, this analysis proposes a different type of model; the explanatory variables are the characteristics of the job $\left(Z_{i t}^{\prime}\right)$ while the dependent variable $\left(H_{i t}^{*}\right)$ is a dummy which is one if the person hired in the job was a unemployed job seeker, and zero if it was an employed job seeker:

$$
H_{i t}^{*}=Z_{i t}^{\prime} \eta+\varepsilon_{i t H}
$$

$Z_{i t}^{\prime}$ includes dummies for permanency, whether or not the actual working hours match the job search criteria, hourly wages, presence of unions at the workplace, the number of days off per year, and commuting time. The latent variable $H_{i t}^{*}$ represents the desirability of the job, and depends on the characteristics of the job itself. What we observe is whether the job offer has been accepted by an employed job seeker, or by unemployed job seeker. Although this setting may seem unusual, it has been used before (e.g. Longhi and Taylor 2014). A positive value of the coefficient $\eta$ would indicate a higher probability that the job has been filled by an unemployed job seeker, keeping constant the other characteristics of the job, while a negative value would indicate a higher probability that the job has been filled by an employed job seeker. If a job with certain characteristics is more likely to be filled by an unemployed 
rather than an employed job seeker, we may speculate that a job with such characteristics may be less likely to be considered acceptable (even if the offer was made) by those who are employed.

The characteristics of the job can only be observed if either an employed or an unemployed job seeker has accepted the job offer. Selection into accepting a job offer is modelled using a probit Heckman selection model (van de Ven and van Praag 1981), where the selection equation is similar to equation (4) but excludes the dummy for employed versus unemployed job seekers and reason for on-the-job search, which would perfectly predict the dependent variable in the main model. All other explanatory variables included in equation (4) are used as instruments for the self-selection equation. In addition, since we observe at most one job acceptance, the selection equation focuses only on the characteristics of the job seeker in the last quarter before accepting a job, or in the last quarter before exiting the LFS sample, thus using cross-section data.

It could be argued that not all variables included in the selection equation are appropriate instruments. For example, education might have a direct impact on some characteristics of the job found such as wages. Such variables should therefore be included in the main model. The empirical part discusses the robustness of the results to changes in the variables included in the two equations.

Another problem is that the selection equation may be misspecified since it excludes the reason for on-the-job search and neglects individual unobserved heterogeneity. The first issue is investigated by comparing the unemployed with employed job seekers who search for different reasons. The second issue, neglected unobserved heterogeneity, is investigated by means of a sensitivity analysis. The intuition behind the sensitivity analysis is that we can interpret the individual unobserved heterogeneity as unobserved time-invariant individual characteristics that increase or decrease the individual's probability of accepting a job offer. The impact of these individual characteristics on the probability of finding a job can be estimated from a longitudinal version of the selection equation, and then included as an additional explanatory variable in the cross-section version of the selection equation. The longitudinal version of the selection equation is estimated using a linear probability model with individual fixed effects with the caveat that the data include only four waves. 


\section{Empirical results}

\subsection{Probability of finding a job}

The marginal effects resulting from the estimation of equations (4) are in Table 2. ${ }^{4}$ For comparison, the first column shows the results of a model estimated using a cross-section probit, while the remaining columns estimate correlated random effect probit models. Columns (1) and (2) show the results of a model including both employed and unemployed job seekers, while the remaining two columns show separate estimations for employed and unemployed job seekers.

Column (2) indicates that even when controlling for differences in search strategy, search duration and a range of observed and unobserved characteristics, employed job seekers have a 28.5 percentage points lower probability than unemployed job seekers of entering a new job. Therefore all else equal, unemployed job seekers are more likely than employed job seekers to receive an acceptable job offer. During recessions, employed job seekers are even less likely than the unemployed to find a job. This is consistent with the idea that the stigma of unemployment is lower during a recession (Clark 2003, Biewen and Steffes 2010), but may also be due to a larger pool of unemployed in these periods, or to an average lower quality of jobs on offer during a recession.

The higher probability that unemployed people find a job and the fact that this difference is larger during a recession is a first indication that the unemployed have a larger pool of job offers that they consider acceptable compared to those who search on-the-job. This is also inconsistent with the signalling theory, which would predict a higher job-finding rate for employed job seekers, although it is still consistent with the dual labour-market theory, which would suggest the existence of two separate labour markets. As described in the theoretical background section, the following step consists in the comparison of the quality of the job found by unemployed and employed job seekers (Section 5.2). Before this, it is useful to analyse the impact of the other covariates.

It is interesting to compare the results of the pooled probit model (column 1) to those of the correlated random effects probit (column 2). The difference between employed and unemployed job seekers appears larger when we account for unobserved heterogeneity, thus suggesting that employed and unemployed job seekers differ systematically in unobservable characteristics. The inclusion of unobserved heterogeneity in the model reduces the level of

\footnotetext{
${ }^{4}$ The marginal effects in the correlated random effect probit models are estimated under the assumption that the individual unobserved heterogeneity is zero.
} 
statistical significance of many of the covariates and in some cases changes the sign of the marginal effects. In particular, the impact of the length of the search is negative in the pooled model, consistent with empirical evidence suggesting that the probability of finding a job decreases with the length of search, but positive in the panel model. The positive impact estimated after controlling individual unobserved heterogeneity suggests that the crosssection results are due to unobserved negative characteristics of job seekers with a longer search time. Those who remain unemployed for longer may have comparatively worse unobserved characteristics which makes them more likely to remain unemployed, all else equal.

Among employed job seekers, those who search because their job may soon come to an end are comparatively more likely to find a job than those who search for any other reason. This is consistent with the idea that workers whose job may soon come to an end have higher incentives to accept job offers, even if they are of lower quality, than other employed job seekers. Since the reference group is unemployed job seekers, this interaction suggests that employed who search because their job may soon come to an end are more similar to the unemployed than to employed job seekers who search for other reasons. This will be investigated in more details in Section 5.4.

Columns (3) and (4) suggest that all search methods are equally productive for employed job seekers, while unemployed who directly approach potential employers as main method of job search seem to have a comparatively lower probability of finding a job. Perhaps the negative signal of unemployment has a higher impact when using this search method. As expected, search intensity, represented by the number of methods of search used, has a positive impact on the probability of finding a job.

Job seekers whose spouse has a part-time job are more likely, while those whose spouse has a temporary job are less likely to accept a job offer; most of these differences disappear when we analyse employed and unemployed job seekers separately.

\section{TABLE 2 ABOUT HERE}

\subsection{Quality of the job found}

Estimates of differences in the quality of the job found by employed and unemployed job seekers are in Table 3 and account for self-selection into accepting a job offer (the results of the selection equations are in the Appendix, Table A1). Positive coefficients indicate a 
higher probability that the job was filled by an unemployed, as opposed to employed job seeker.

While information on hours sought and permanency have been collected each quarter consistently since the beginning of the quarterly survey, data on wages have been asked only in the first and fifth interview, while data on the presence of unions, number of days off and commuting time have been asked irregularly and only since 2004. Table 3 shows various model specifications which progressively include more variables, at the cost of a reduced sample size.

The results suggest that temporary jobs are more likely to be filled by unemployed job seekers, and that unemployed job seekers are less likely to accept job offers that satisfy their requirements in term of working hours. Unemployed job seekers are also more likely than employed job seekers to accept jobs offering comparatively lower wages. These results are consistent whether we include imputed values for wages or not, although including imputed wages tends to result in comparatively larger marginal effects. In other words, columns (2) and (3) of Table 3 suggest that unemployed job seekers are hired in jobs that pay about 0.10.5 percentage points lower wages, have a 1.4-5.1 percentage points higher probability of being temporary instead of permanent, and a 1.3-4.8 percentage points lower probability of offering the amount of working hours sought. If we consider that average wages in this dataset are about $£ 8.77$ and the proportion of temporary jobs is about $25 \%$, these differences may be considered small.

This suggests that both unemployed and employed job seekers find similar quality jobs once we control for characteristics and self-selection into accepting a job offer. The results are consistent with the idea that the main reason why unemployed people find lower quality jobs is due to their willingness to accept any job while factors such as negative signals and labour market constraints do not seem to play a relevant role in the outcome.

\section{TABLE 3 ABOUT HERE}

Columns (4) and (5) of Table 3 include dummies for the presence of unions in the workplace, the number of days off, and commuting time. The results still suggest that unemployed job seekers are more likely to accept jobs that are temporary (consistent with Böheim and Taylor 2002), do not satisfy their working hour requirements, and pay comparatively lower wages. In addition, they seem more likely to accept jobs where unions are not present, and perhaps with comparatively shorter commuting time and more days off. 
Most of the marginal effects however, become statistically insignificant, and this is likely due to the small number of observations.

\subsection{Sensitivity}

The results are robust to changes in the variables included in the selection equations and in the main model. The first two columns of Table A2 in the Appendix show models that exclude education and the recession dummy from the selection equation and include them in the main model. The results are similar both in sign and in magnitude to those in Table 3. At the extreme, we can estimate a model in which all variables are included in the main model and there is no selection equation. Such a model, estimated using a probit, gives similar marginal effects for wages and larger marginal effect for the other two variables. In this case unemployed people have about 8-9 percentage points higher probability of being hired in temporary jobs, and 7-11 percentage points lower probability of being hired in jobs that satisfy their requirements in terms of working hours compared to employed job seekers. Such larger marginal effects are consistent with the previous conclusions that most of the difference in the quality of the job found by employed and unemployed job seekers is due to the pressure of accepting - any - job, even if it is of lower quality, rather than constraints imposed by the labour market. The larger differences for other job characteristics compared to wages suggest that the unemployed are less likely to trade-off wages for other job characteristics when evaluating job offers. This is consistent with the unemployed facing more financial constraints than employed job seekers. When such differences in jobacceptance behaviour are taken into account, the jobs found by the unemployed are of very similar quality than the job found by employed job seekers, thus suggesting little or no role of labour market constraints.

As a second sensitivity analysis an alternative probit Heckman selection model is estimated, which partly accounts for individual unobserved heterogeneity in the selection equation. The results are shown in the last two columns of Table A2 of the Appendix and are generally consistent with those in Table 3 . The main difference is an increase in the marginal effects, which are also more stable across specifications. Unemployed job seekers tend to be hired in jobs that pay on average about 1 percentage points lower wages, have a 12-14 percentage points higher probability of being temporary instead of permanent, and a 10 percentage points lower probability of offering the amount of working hours sought.

Overall these results suggest that unemployed job seekers enter jobs that are of systematically lower quality than employed job seekers, but that the difference between the 
two is tiny once we control for observed and unobserved characteristics, and for the probability of accepting a job offer.

\subsection{Differences by reason of job search}

While almost $60 \%$ of employed job seekers state that the main reason for searching for a new job is that they find some aspects of their job unsatisfactory, $14.3 \%$ search because their current job may soon come to an end (see Table 1). Similarly to the unemployed, employed job seekers who search because their job may soon come to an end may feel financial pressure to accept a job offer; however, similar to the other employed job seekers, they do not carry a negative signal of unemployment. Given the results in the previous section, the expectation is that the quality of the job found by employed job seekers who search because their job may soon come to an end will be the same as for other employed job seekers, while the job-finding rate should fall between that of the unemployed and that of employed searching for other reasons.

Table 4 shows the probability of finding a job for (1) the unemployed compared to employed job seekers who search because their job may soon come to an end, and (2) employed who search because their job may soon come to an end compared to employed searching for any other reason. The reference group is unemployed in column (1) and employed job seekers who search for other reasons in column (2). Employed who search for other reasons are excluded from the model in column (1), while the unemployed are excluded from the model in column (2). The results suggest that employed job seekers who search because their job may soon come to an end have a similar probability of finding a job than the unemployed (column 1); the difference is statistically significant only at the $10 \%$ level. Employed job seekers who search because their job may soon come to an end are about 2.4 percentage points more likely to accept a job than employed job seekers who search for other reasons. The marginal effects of the other explanatory variables are consistent with those in Table 2.

\section{TABLE 4 ABOUT HERE}

Table 5 focuses on the quality of the job found. While column (1) shows the results of a multinomial probit, not accounting for self-selection into accepting a job offer, the following columns show the results of Heckman selection models. The selection models compare the unemployed to employed job seekers searching because their job may soon 
come to an end (column 2) and employed job seekers searching because their job may soon come to an end to those searching for any other reason (column 3).

The models suggest that, compared to the unemployed, employed job seekers who search because their job may soon come to an end are more likely to find jobs that meet their requirements in terms of working hours and that pay higher wages. However, there seem to be no difference in the probability of finding a temporary job. Compared to employed job seekers who search because their job may soon come to an end, those who search for any other reason are less likely to accept a temporary position, while there seem to be no differences in terms of actual working hours compared to what sought, and in terms of wages.

\section{TABLE 5 ABOUT HERE}

\section{Conclusions}

This paper compares job search outcomes of employed and unemployed job seekers. The aim is to analyse whether differences in outcomes are related to different behaviours and choices made by unemployed and employed job seekers instead of being dictated by the labour market (i.e. being due to signalling and to the presence of a dual labour market). The results indicate that unemployed people have a higher probability than employed job seekers of accepting a job offer, even after controlling for various individual and household characteristics and individual unobserved heterogeneity. After controlling for heterogeneity in the probability of finding a job, the results suggest that wages obtained by unemployed job seekers are comparatively lower than those obtained by employed job seekers, but the difference is small. Employed job seekers are also slightly more likely to obtain permanent jobs and jobs that satisfy their requirements in terms of working hours.

Employed job seekers who search because their job may soon come to an end have the same probability of accepting a job offer than the unemployed, and this is higher than the probability for employed who search for other reasons. Nevertheless, they find jobs that are of the same quality (in terms of wages and working hours) than those found by other employed job seekers, and of better quality than jobs accepted by the unemployed. In terms of permanency, the employed who search because their job may soon come to an end are more similar to the unemployed than to other employed job seekers (in contrast with Booth et al. 2002). 
Differences in job search outcomes between unemployed and employed job seekers are rather small once we control for observed and unobserved characteristics. This suggests that they may be due to differences in the pool of job offers that each job seeker considers acceptable. The unemployed may be subject to comparatively higher pressure to find a job: they accept jobs too quickly and accept worse quality jobs on average. Hence, the pressure that unemployed people may feel to accept any job may have a positive impact on their probability of finding a job, but also negative consequences on the quality of the job found and on subsequent (employment) careers. The results do not show evidence of the unemployed being channelled in a secondary labour market characterised by bad jobs.

The results suggest that the unemployed may obtain good quality jobs, comparable to those found by employed job seekers, if they can afford to wait longer for a better job offer. This adds evidence that financial incentives such as unemployment and benefits may allow (certain types of) unemployed people to search for longer and obtain overall better and more stable jobs with positive net effects for welfare, consistent with Caliendo et al. (2013), van den Berg and Vikström (2014), Nekoei and Weber (2015).

\section{References}

Arulampalam, W. (2001) Is Unemployment Really Scarring? Effects of Unemployment Experiences on Wages. The Economic Journal 111(475): F585-F606.

Arulampalam, W., Gregg, P. and Gregory, M. (2001) Unemployment Scarring. The Economic Journal 111: F577-F584.

Biewen, M. and Steffes, S. (2010) Unemployment Persistence: Is There Evidence for Stigma Effects? Economics Letters 106: 188-190.

Blanchard, O.J. and Diamond, P.A. (1994) Ranking Employment Duration and Wages. Review of Economic Studies 61: 417-434.

Blau, D.M. and Robins, P.K. (1990) Job Search Outcomes for the Employed and Unemployed. Journal of Political Economy 98(3): 637-655.

Böheim, R. and Taylor, M.P. (2002) The Search for Success: Do the Unemployed Find Stable Employment? Labour Economics 9(6): 717-735.

Bonhomme, S. and Jolivet, G. (2009) The Pervasive Absence of Compensating Differentials. Journal of Applied Econometrics 24: 763-795.

Booth, A.L., Francesconi, M. and Frank, J. (2002) Temporary Jobs: Stepping Stones or Dead Ends? The Economic Journal 112(480): F189-F213.

Caliendo, M., Tatsiramos, K. and Uhlendorff, A. (2013) Benefit Duration, Unemployment Duration and Job Match Quality: A Regression-Discontinuity Approach. Journal of Applied Econometrics 28: 604-627.

Clark, A.E. (2003) Unemployment as a Social Norm: Psychological Evidence from Panel Data. Journal of Labor Economics 21(2): 323-351.

Eriksson, S. and Gottfries, N. (2005) Ranking of Job Applicants, on-the-Job Search, and Persistent Unemployment. Labour Economics 12: 407-428.

Eriksson, S. and Lagerstrom, J. (2006) Competition between Employed and Unemployed Job Applicants: Swedish Evidence. Scandinavian Journal of Economics 108(3): 373-396. 
Gregg, P. and Tominey, E. (2005) The Wage Scar from Male Youth Unemployment. Labour Economics 12: 487-509.

Gruetter, M. and Lalive, R. (2009) The Importance of Firms in Wage Determination. Labour Economics 16: 149-160.

Gush, K., Scott, J. and Laurie, H. (2015) Household's Responses to Spousal Job Loss: 'All Change' or 'Carry on as Usual'? Work Employment and Society Forthcoming.

Kuhn, P. and Mansour, H. (2014) Is Internet Job Search Still Ineffective? The Economic Journal 124: 1213-1233.

Longhi, S. and Taylor, M. (2014) Employed and Unemployed Job Seekers and the Business Cycle. Oxford Bulletin of Economics and Statistics 76(4): 463-483.

Mundlak, Y. (1978) On the Pooling of Time Series and Cross Section Data. Econometrica 46(1): 69-85.

Nekoei, A. and Weber, A. (2015) Does Extending Unemployment Benefits Improve Job Quality?, IZA Discussion Paper No. 9034.

Pissarides, C.A. (1994) Search Unemployment with on-the-Job Search. Review of Economic Studies 61: 457-475.

Rogerson, R., Shimer, R. and Wright, R. (2005) Search-Theoretic Models of the Labor Market: A Survey. Journal of Economic Literature 43(December): 959-988.

Sullivan, P. and To, T. (2014) Search and Nonwage Job Characteristics. Journal of Human Resources 49(2): 472-507.

van de Ven, W.P. and van Praag, B.M. (1981) The Demand for Deductibles in Private Health Insurance. Journal of Econometrics 17: 229-252.

van den Berg, G.J. and Vikström, J. (2014) Monitoring Job Offer Decisions, Punishments, Exit to Work, and Job Quality. The Scandinavian Journal of Economics 116(2): 284334.

Weber, A. and Mahringer, H. (2008) Choice and Success of Job Search Methods. Empirical Economics 35: 153-178.

Wooldridge, J.M. (2010) Correlated Random Effects Models with Unbalanced Panels, Department of Economics, Michigan State University. 


\section{Tables and figures}

Table 1: Descriptive statistics for unemployed and employed job seekers

\begin{tabular}{|c|c|c|}
\hline & $\begin{array}{l}\text { Unemployed } \\
\text { job seekers }\end{array}$ & $\begin{array}{l}\text { Employed } \\
\text { job seekers }\end{array}$ \\
\hline Number of Observations & 45,809 & 43,952 \\
\hline \multicolumn{3}{|l|}{ Main search method } \\
\hline Job centres, private career offices etc. & 0.385 & 0.146 \\
\hline Ads in newspapers & 0.407 & 0.644 \\
\hline Direct approach employers & 0.085 & 0.073 \\
\hline Ask friends/relatives & 0.108 & 0.101 \\
\hline Do anything else & 0.015 & 0.036 \\
\hline No. of search methods & 4.7 & 3.3 \\
\hline \multicolumn{3}{|l|}{ Reason for search on-the-job } \\
\hline Job may come to an end & & 0.143 \\
\hline Pay unsatisfactory & & 0.263 \\
\hline Other aspects of job unsatisfactory & & 0.319 \\
\hline Other reasons & & 0.275 \\
\hline Searching 0-3 months & 0.245 & 0.404 \\
\hline Searching 3-12 months & 0.314 & 0.337 \\
\hline Searching > 12 months & 0.441 & 0.259 \\
\hline Age & 40 & 38 \\
\hline Children (18 or younger) & 0.246 & 0.354 \\
\hline \multicolumn{3}{|l|}{ Education level } \\
\hline NVQ level 4 and above & 0.145 & 0.365 \\
\hline NVQ level 3 & 0.216 & 0.228 \\
\hline NVQ level 2 and below & 0.228 & 0.236 \\
\hline Other qualifications & 0.155 & 0.109 \\
\hline No qualifications & 0.256 & 0.063 \\
\hline \multicolumn{3}{|l|}{ Spouse information } \\
\hline No spouse information & 0.708 & 0.426 \\
\hline Spouse has job (includes self-employed) & 0.647 & 0.905 \\
\hline Hourly wages employed spouse ( $£$ when data available) & 7.62 & 8.51 \\
\hline Spouse has part-time job & 0.464 & 0.417 \\
\hline Spouse has temporary job & 0.065 & 0.070 \\
\hline \multicolumn{3}{|l|}{ Outcomes of interest } \\
\hline Proportion finding a job & 0.072 & 0.066 \\
\hline Quality of the new job found (observations) & $(1,706)$ & $(2,043)$ \\
\hline Hourly wage $(£)$ & 7.70 & 9.66 \\
\hline Temporary job & 0.321 & 0.198 \\
\hline Part/Full-time as desired & 0.910 & 0.952 \\
\hline Commuting time in minutes (observations: $189-198$ ) & 28 & 36 \\
\hline Unions at workplace (observations: $180-245$ ) & 0.383 & 0.424 \\
\hline Number days off (observations: $179-240$ ) & 34 & 29 \\
\hline
\end{tabular}


Table 2: Determinants of unemployed and employed job seekers finding a job

\begin{tabular}{|c|c|c|c|c|}
\hline & $\begin{array}{c}(1) \\
\text { Probability } \\
\text { of finding } \\
\text { a job }\end{array}$ & $\begin{array}{c}(2) \\
\text { Probability } \\
\text { of finding } \\
\text { a job }\end{array}$ & $\begin{array}{c}(3) \\
\text { Probability that } \\
\text { unemployed } \\
\text { seeker } \\
\text { finds a job } \\
\end{array}$ & $\begin{array}{c}\text { (4) } \\
\text { Probability that } \\
\text { employed } \\
\text { job seeker } \\
\text { finds a job } \\
\end{array}$ \\
\hline Employed job seeker & $\begin{array}{c}-0.053^{*} \\
(0.007)\end{array}$ & $\begin{array}{l}-0.285^{*} \\
(0.022)\end{array}$ & & \\
\hline \multicolumn{5}{|c|}{ Search method (ref: job centres, career offices etc.): } \\
\hline Ads in newspapers & $\begin{array}{c}-0.004+ \\
(0.002)\end{array}$ & $\begin{array}{l}-0.004 \\
(0.004)\end{array}$ & $\begin{array}{l}-0.004 \\
(0.005)\end{array}$ & $\begin{array}{l}-0.004 \\
(0.008)\end{array}$ \\
\hline Direct approach employers & $\begin{array}{c}0.005 \\
(0.003)\end{array}$ & $\begin{array}{l}-0.002 \\
(0.007)\end{array}$ & $\begin{array}{c}-0.014+ \\
(0.006)\end{array}$ & $\begin{array}{c}0.015 \\
(0.013)\end{array}$ \\
\hline Ask friends/relatives & $\begin{array}{c}0.004 \\
(0.003)\end{array}$ & $\begin{array}{l}-0.001 \\
(0.006)\end{array}$ & $\begin{array}{l}-0.007 \\
(0.007)\end{array}$ & $\begin{array}{c}0.016 \\
(0.013)\end{array}$ \\
\hline Do anything else & $\begin{array}{l}-0.002 \\
(0.005)\end{array}$ & $\begin{array}{c}0.007 \\
(0.012)\end{array}$ & $\begin{array}{c}0.008 \\
(0.017)\end{array}$ & $\begin{array}{l}-0.012 \\
(0.013)\end{array}$ \\
\hline No. search methods & $\begin{array}{l}0.012 * \\
(0.000)\end{array}$ & $\begin{array}{l}0.007 * \\
(0.001)\end{array}$ & $\begin{array}{l}0.006^{*} \\
(0.001)\end{array}$ & $\begin{array}{l}0.010^{*} \\
(0.001)\end{array}$ \\
\hline \multicolumn{5}{|c|}{ Reason for search on-the-job (ref: unemployed/other reasons) } \\
\hline Job may come to an end & $\begin{array}{l}0.083^{*} \\
(0.011)\end{array}$ & $\begin{array}{l}0.076^{*} \\
(0.024)\end{array}$ & & $\begin{array}{l}0.036^{*} \\
(0.012)\end{array}$ \\
\hline Pay unsatisfactory & $\begin{array}{l}0.042 * \\
(0.009)\end{array}$ & $\begin{array}{l}0.038+ \\
(0.018)\end{array}$ & & $\begin{array}{c}0.009 \\
(0.008)\end{array}$ \\
\hline Other aspects of job unsatisfactory & $\begin{array}{l}0.041 * \\
(0.009)\end{array}$ & $\begin{array}{l}0.038+ \\
(0.018)\end{array}$ & & $\begin{array}{c}0.007 \\
(0.008)\end{array}$ \\
\hline Other reasons & $\begin{array}{l}0.042 * \\
(0.009)\end{array}$ & $\begin{array}{c}0.028 \\
(0.017)\end{array}$ & & \\
\hline Searching 3-12 months & $\begin{array}{l}-0.024^{*} \\
(0.002)\end{array}$ & $\begin{array}{l}0.046^{*} \\
(0.004)\end{array}$ & $\begin{array}{l}0.074 * \\
(0.007)\end{array}$ & $\begin{array}{l}0.027 * \\
(0.006)\end{array}$ \\
\hline Searching $>12$ months & $\begin{array}{l}-0.060 * \\
(0.002)\end{array}$ & $\begin{array}{l}0.095^{*} \\
(0.009)\end{array}$ & $\begin{array}{l}0.168^{*} \\
(0.015)\end{array}$ & $\begin{array}{l}0.049 * \\
(0.011)\end{array}$ \\
\hline Age (10 years) & $\begin{array}{c}-0.003^{*} \\
(0.001)\end{array}$ & $\begin{array}{c}0.003 \\
(0.013)\end{array}$ & $\begin{array}{c}0.022 \\
(0.016)\end{array}$ & $\begin{array}{l}-0.013 \\
(0.025)\end{array}$ \\
\hline Children (18 or younger) & $\begin{array}{l}-0.001 \\
(0.002)\end{array}$ & $\begin{array}{l}-0.006 \\
(0.013)\end{array}$ & $\begin{array}{c}-0.022 \\
(0.014)\end{array}$ & $\begin{array}{c}0.019 \\
(0.021)\end{array}$ \\
\hline Education level (ref: NVQ level 4 a & d above) & & & \\
\hline NVQ level 3 & $\begin{array}{l}-0.000 \\
(0.002)\end{array}$ & $\begin{array}{c}0.013 \\
(0.015)\end{array}$ & $\begin{array}{c}0.006 \\
(0.018)\end{array}$ & $\begin{array}{c}0.035 \\
(0.028)\end{array}$ \\
\hline NVQ level 2 and below & $\begin{array}{c}0.000 \\
(0.002)\end{array}$ & $\begin{array}{c}0.009 \\
(0.016)\end{array}$ & $\begin{array}{l}-0.000 \\
(0.018)\end{array}$ & $\begin{array}{c}0.034 \\
(0.031)\end{array}$ \\
\hline Other qualifications & $\begin{array}{l}-0.001 \\
(0.003)\end{array}$ & $\begin{array}{c}0.006 \\
(0.016)\end{array}$ & $\begin{array}{c}0.003 \\
(0.019)\end{array}$ & $\begin{array}{c}0.027 \\
(0.033)\end{array}$ \\
\hline No qualifications & $\begin{array}{l}-0.020^{*} \\
(0.003)\end{array}$ & $\begin{array}{l}-0.001 \\
(0.016)\end{array}$ & $\begin{array}{l}-0.001 \\
(0.019)\end{array}$ & $\begin{array}{c}0.003 \\
(0.031)\end{array}$ \\
\hline Spouse information & & & & \\
\hline No spouse information & $\begin{array}{c}-0.018^{*} \\
(0.003)\end{array}$ & $\begin{array}{l}-0.020 \\
(0.017)\end{array}$ & $\begin{array}{c}0.003 \\
(0.020)\end{array}$ & $\begin{array}{l}-0.039 \\
(0.026)\end{array}$ \\
\hline Spouse has job & $\begin{array}{l}0.012 * \\
(0.004)\end{array}$ & $\begin{array}{l}-0.028 \\
(0.014)\end{array}$ & $\begin{array}{l}-0.017 \\
(0.019)\end{array}$ & $\begin{array}{l}-0.027 \\
(0.024)\end{array}$ \\
\hline Hourly wages employed spouse & $\begin{array}{l}-0.000 \\
(0.000)\end{array}$ & $\begin{array}{l}-0.000 \\
(0.001)\end{array}$ & $\begin{array}{l}-0.000 \\
(0.002)\end{array}$ & $\begin{array}{c}0.000 \\
(0.001)\end{array}$ \\
\hline Spouse has part-time job & $\begin{array}{c}0.003 \\
(0.003)\end{array}$ & $\begin{array}{l}0.031+ \\
(0.016)\end{array}$ & $\begin{array}{c}0.042 \\
(0.029)\end{array}$ & $\begin{array}{c}0.020 \\
(0.019)\end{array}$ \\
\hline
\end{tabular}




\begin{tabular}{lcccc} 
Spouse has temporary job & $-0.016^{*}$ & $-0.022+$ & -0.011 & $-0.025+$ \\
& $(0.004)$ & $(0.011)$ & $(0.019)$ & $(0.012)$ \\
Recession & $-0.157^{*}$ & $-0.150^{*}$ & & \\
& $(0.001)$ & $(0.003)$ & & \\
Recession * Employed job seeker & $-0.017^{*}$ & $-0.033^{*}$ & & \\
& $(0.005)$ & $(0.008)$ & & yes \\
Unobserved heterogeneity & no & yes & yes & -9949 \\
Log likelihood & -20857 & -19932 & -10332 & 43,952 \\
Observations & 89,761 & 89,761 & 45,809 & \\
\hline
\end{tabular}

Marginal effects of probit model (column 1) and of correlated random effect probit models (columns 2-4); dependent variable $=1$ if job seeker entered a (new) job by the subsequent quarter, and $=0$ otherwise; standard errors in parenthesis are clustered by individuals in column (1). Other explanatory variables: dummies for government office region, year, quarter, and mean of the time-varying covariates (columns 2-4).

+ Significant at $5 \%, *$ Significant at $1 \%$.

Table 3: Quality of the job found by unemployed and employed job seekers

\begin{tabular}{|c|c|c|c|c|c|}
\hline Characteristics of accepted job & (1) & (2) & (3) & (4) & (5) \\
\hline Wage (£ per hour) & & $\begin{array}{c}-0.005^{*} \\
(0.001)\end{array}$ & $\begin{array}{l}-0.001 * \\
(0.000)\end{array}$ & $\begin{array}{c}-0.003+ \\
(0.001)\end{array}$ & $\begin{array}{c}-0.002 \\
(0.001)\end{array}$ \\
\hline Temporary & $\begin{array}{l}0.037 * \\
(0.004)\end{array}$ & $\begin{array}{l}0.051^{*} \\
(0.009)\end{array}$ & $\begin{array}{l}0.014^{*} \\
(0.004)\end{array}$ & $\begin{array}{c}0.039 \\
(0.020)\end{array}$ & $\begin{array}{c}0.012 \\
(0.015)\end{array}$ \\
\hline Working hrs same as sought & $\begin{array}{c}-0.034 * \\
(0.005)\end{array}$ & $\begin{array}{c}-0.048^{*} \\
(0.011)\end{array}$ & $\begin{array}{c}-0.013^{*} \\
(0.004)\end{array}$ & $\begin{array}{l}-0.029 \\
(0.030)\end{array}$ & $\begin{array}{c}-0.029 \\
(0.022)\end{array}$ \\
\hline Commuting time (in 10 minutes) & & & & & $\begin{array}{c}-0.003 \\
(0.002)\end{array}$ \\
\hline Presence of unions & & & & $\begin{array}{l}-0.022 \\
(0.019)\end{array}$ & $\begin{array}{c}-0.003 \\
(0.013)\end{array}$ \\
\hline Number of days off & & & & $\begin{array}{c}0.001 \\
(0.000)\end{array}$ & $\begin{array}{c}0.000 \\
(0.000)\end{array}$ \\
\hline Imputed values & no & yes & no & yes & yes \\
\hline Log likelihood (full model) & -2195 & -14921 & -6335 & -1881 & -1244 \\
\hline LR test of indep. eqns. $($ rho $=0)$ & $297.14 *$ & $101.70^{*}$ & $74.20 *$ & $23.61^{*}$ & $20.10^{*}$ \\
\hline Observations & 6,165 & 3,749 & 1,272 & 419 & 252 \\
\hline Time & $1992-2010$ & $1992-2010$ & 1992-2010 & 2004-2010 & 2004-2010 \\
\hline
\end{tabular}

Marginal effects of Heckman selection probit models; dependent variable $=1$ if person hired in the job was unemployed, and $=0$ if it was an employed job seeker; see Table A1, columns 1-5 for self-selection equation.

+ Significant at $5 \%, *$ Significant at $1 \%$. Standard errors in parenthesis. 
Table 4: Determinants of the probability of finding a job, by reason of search

\begin{tabular}{|c|c|c|}
\hline & $\begin{array}{c}\text { (1) } \\
\text { Reference: } \\
\text { unemployed }\end{array}$ & $\begin{array}{c}\text { (2) } \\
\text { Reference: } \\
\text { Employed searching } \\
\text { for any other reason }\end{array}$ \\
\hline Employed searching because job may soon come to an end & $\begin{array}{l}-0.005 \\
(0.003)\end{array}$ & $\begin{array}{l}0.024^{*} \\
(0.004)\end{array}$ \\
\hline Search method (ref: job centres, career offices etc.): & & \\
\hline Ads in newspapers & $\begin{array}{l}-0.007 \\
(0.005)\end{array}$ & $\begin{array}{l}-0.004 \\
(0.007)\end{array}$ \\
\hline Direct approach employers & $\begin{array}{c}-0.015+ \\
(0.007)\end{array}$ & $\begin{array}{c}0.013 \\
(0.013)\end{array}$ \\
\hline Ask friends/relatives & $\begin{array}{l}-0.006 \\
(0.007)\end{array}$ & $\begin{array}{l}0.015 \\
(0.013)\end{array}$ \\
\hline Do anything else & $\begin{array}{c}0.010 \\
(0.018)\end{array}$ & $\begin{array}{l}-0.007 \\
(0.013)\end{array}$ \\
\hline No. search methods & $\begin{array}{l}0.010^{*} \\
(0.001)\end{array}$ & $\begin{array}{l}0.010^{*} \\
(0.001)\end{array}$ \\
\hline Searching 3-12 months & $\begin{array}{l}0.050^{*} \\
(0.006)\end{array}$ & $\begin{array}{l}0.019 * \\
(0.006)\end{array}$ \\
\hline Searching $>12$ months & $\begin{array}{l}0.103 * \\
(0.012)\end{array}$ & $\begin{array}{l}0.041 * \\
(0.011)\end{array}$ \\
\hline Age (10 years) & $\begin{array}{c}0.006 \\
(0.016)\end{array}$ & $\begin{array}{l}-0.027 \\
(0.022)\end{array}$ \\
\hline Children (18 or younger) & $\begin{array}{l}-0.022 \\
(0.015)\end{array}$ & $\begin{array}{c}0.018 \\
(0.021)\end{array}$ \\
\hline Education level (ref: NVQ level 4 and above) & & \\
\hline NVQ level 3 & $\begin{array}{c}0.009 \\
(0.019)\end{array}$ & $\begin{array}{c}0.043 \\
(0.030)\end{array}$ \\
\hline NVQ level 2 and below & $\begin{array}{l}-0.001 \\
(0.019)\end{array}$ & $\begin{array}{c}0.040 \\
(0.032)\end{array}$ \\
\hline Other qualifications & $\begin{array}{c}0.007 \\
(0.021)\end{array}$ & $\begin{array}{c}0.035 \\
(0.035)\end{array}$ \\
\hline No qualifications & $\begin{array}{l}-0.003 \\
(0.020)\end{array}$ & $\begin{array}{c}0.004 \\
(0.029)\end{array}$ \\
\hline Spouse information & & \\
\hline No spouse information & $\begin{array}{l}-0.003 \\
(0.021)\end{array}$ & $\begin{array}{l}-0.035 \\
(0.027)\end{array}$ \\
\hline Spouse has job & $\begin{array}{l}-0.019 \\
(0.019)\end{array}$ & $\begin{array}{l}-0.023 \\
(0.020)\end{array}$ \\
\hline Hourly wages employed spouse & $\begin{array}{l}-0.001 \\
(0.002)\end{array}$ & $\begin{array}{c}0.000 \\
(0.001)\end{array}$ \\
\hline Spouse has part-time job & $\begin{array}{c}0.038 \\
(0.029)\end{array}$ & $\begin{array}{c}0.017 \\
(0.019)\end{array}$ \\
\hline Spouse has temporary job & $\begin{array}{l}-0.019 \\
(0.017)\end{array}$ & $\begin{array}{l}-0.020 \\
(0.012)\end{array}$ \\
\hline $\begin{array}{l}\text { Log likelihood } \\
\text { Observations }\end{array}$ & $\begin{array}{l}-10991 \\
49,330\end{array}$ & $\begin{array}{c}-7894 \\
37,973\end{array}$ \\
\hline
\end{tabular}

Marginal effects of correlated random effect probit models; dependent variable $=1$ if job seeker entered a (new) job by the subsequent quarter, and $=0$ otherwise; standard errors in parenthesis. Other explanatory variables: dummies for government office region, year, quarter, and mean of the time-varying covariates.

+ Significant at $5 \%, *$ Significant at $1 \%$. 
Table 5: Quality of the job found by unemployed and employed job seekers, by reason for on-the-job search

\begin{tabular}{|c|c|c|c|c|}
\hline \multirow[b]{2}{*}{ Characteristics of accepted job } & \multicolumn{2}{|c|}{$\begin{array}{c}(1) \\
\text { Ref: unemployed }\end{array}$} & \multirow{2}{*}{$\begin{array}{c}\text { (2) } \\
\text { Ref: } \\
\text { unemployed } \\
\text { Employed } \\
\text { job may end }\end{array}$} & \multirow{2}{*}{$\begin{array}{c}(3) \\
\text { Ref: Employed } \\
\text { any other reason } \\
\text { Employed } \\
\text { job may end }\end{array}$} \\
\hline & $\begin{array}{l}\text { Employed } \\
\text { job may end }\end{array}$ & $\begin{array}{c}\text { Employed } \\
\text { any other reason }\end{array}$ & & \\
\hline \multirow[t]{2}{*}{ Wage (£ per hour) } & $0.002+$ & $0.005^{*}$ & $0.002 *$ & 0.001 \\
\hline & $(0.001)$ & $(0.001)$ & $(0.001)$ & $(0.001)$ \\
\hline \multirow[t]{2}{*}{ Temporary } & $0.054 *$ & $-0.139 *$ & 0.002 & $0.212^{*}$ \\
\hline & $(0.012)$ & $(0.016)$ & $(0.005)$ & $(0.030)$ \\
\hline \multirow[t]{2}{*}{ Working hrs same as sought } & 0.039 & 0.035 & $0.022 *$ & 0.035 \\
\hline & $(0.024)$ & $(0.030)$ & $(0.007)$ & $(0.054)$ \\
\hline Log likelihood (full model) & \multicolumn{2}{|r|}{-6617} & -9184 & -9060 \\
\hline LR test of indep. eqns. $($ rho $=0)$ & & & $44.03 *$ & $8.26^{*}$ \\
\hline Observations & \multicolumn{2}{|r|}{6,999} & 2,182 & 2,043 \\
\hline
\end{tabular}


Table A1: Selection model for quality of the job found by unemployed and employed job seekers

\begin{tabular}{|c|c|c|c|c|c|c|c|}
\hline Characteristics of accepted job & \multicolumn{5}{|c|}{ Unemployed and employed job seekers } & $\begin{array}{c}6) \\
\text { Unemployed and } \\
\text { employed job seekers } \\
\text { searching because } \\
\text { job may come to an end }\end{array}$ & $\begin{array}{c}(7) \\
\text { Employed job seekers } \\
\text { searching because job may end } \\
\text { and employed job seekers } \\
\text { searching for other reasons }\end{array}$ \\
\hline \multicolumn{8}{|c|}{ Search method (ref: job centres, career offices etc.): } \\
\hline Ads in newspapers & $\begin{array}{l}-0.138^{*} \\
(0.016)\end{array}$ & $\begin{array}{c}-0.109^{*} \\
(0.020)\end{array}$ & $\begin{array}{l}-0.136^{*} \\
(0.028)\end{array}$ & $\begin{array}{l}-0.030 \\
(0.057)\end{array}$ & $\begin{array}{c}0.003 \\
(0.068)\end{array}$ & $\begin{array}{c}-0.157^{*} \\
(0.025)\end{array}$ & $\begin{array}{c}0.047 \\
(0.028)\end{array}$ \\
\hline Direct approach employers & $\begin{array}{l}-0.068^{*} \\
(0.025)\end{array}$ & $\begin{array}{l}-0.059 \\
(0.032)\end{array}$ & $\begin{array}{l}-0.126^{*} \\
(0.045)\end{array}$ & $\begin{array}{c}0.017 \\
(0.101)\end{array}$ & $\begin{array}{l}-0.009 \\
(0.126)\end{array}$ & $\begin{array}{l}-0.125^{*} \\
(0.040)\end{array}$ & $\begin{array}{l}0.125^{*} \\
(0.041)\end{array}$ \\
\hline Ask friends/relatives & $\begin{array}{l}-0.071^{*} \\
(0.024)\end{array}$ & $\begin{array}{l}-0.081 * \\
(0.031)\end{array}$ & $\begin{array}{r}-0.102+ \\
(0.042)\end{array}$ & $\begin{array}{c}0.040 \\
(0.093)\end{array}$ & $\begin{array}{l}0.041 \\
(0.114)\end{array}$ & $\begin{array}{l}-0.140^{*} \\
(0.038)\end{array}$ & $\begin{array}{l}0.067 \\
(0.040)\end{array}$ \\
\hline Do anything else & $\begin{array}{l}-0.144^{*} \\
(0.043)\end{array}$ & $\begin{array}{l}-0.147^{*} \\
(0.055)\end{array}$ & $\begin{array}{c}-0.172+ \\
(0.079)\end{array}$ & $\begin{array}{l}-0.137 \\
(0.159)\end{array}$ & $\begin{array}{l}-0.207 \\
(0.209)\end{array}$ & $\begin{array}{l}-0.227^{*} \\
(0.074)\end{array}$ & $\begin{array}{c}0.009 \\
(0.065)\end{array}$ \\
\hline No. search methods & $\begin{array}{l}0.139^{*} \\
(0.004)\end{array}$ & $\begin{array}{l}0.140 * \\
(0.004)\end{array}$ & $\begin{array}{l}0.136^{*} \\
(0.006)\end{array}$ & $\begin{array}{l}0.127^{*} \\
(0.011)\end{array}$ & $\begin{array}{l}0.134 * \\
(0.014)\end{array}$ & $\begin{array}{l}0.186^{*} \\
(0.006)\end{array}$ & $\begin{array}{l}0.042^{*} \\
(0.006)\end{array}$ \\
\hline Searching 3-12 months & $\begin{array}{l}-0.131^{*} \\
(0.015)\end{array}$ & $\begin{array}{l}-0.146^{*} \\
(0.019)\end{array}$ & $\begin{array}{l}-0.096^{*} \\
(0.026)\end{array}$ & $\begin{array}{r}-0.114+ \\
(0.050)\end{array}$ & $\begin{array}{l}-0.010 \\
(0.059)\end{array}$ & $\begin{array}{l}-0.195^{*} \\
(0.024)\end{array}$ & $\begin{array}{l}-0.163^{*} \\
(0.024)\end{array}$ \\
\hline Searching $>12$ months & $\begin{array}{l}-0.429 * \\
(0.020)\end{array}$ & $\begin{array}{l}-0.452^{*} \\
(0.024)\end{array}$ & $\begin{array}{l}-0.356^{*} \\
(0.033)\end{array}$ & $\begin{array}{l}-0.443^{*} \\
(0.069)\end{array}$ & $\begin{array}{l}-0.363^{*} \\
(0.081)\end{array}$ & $\begin{array}{l}-0.523^{*} \\
(0.029)\end{array}$ & $\begin{array}{l}-0.485^{*} \\
(0.030)\end{array}$ \\
\hline Age (10 years) & $\begin{array}{l}0.018^{*} \\
(0.006)\end{array}$ & $\begin{array}{l}0.029 * \\
(0.008)\end{array}$ & $\begin{array}{c}0.014 \\
(0.011)\end{array}$ & $\begin{array}{l}0.056^{*} \\
(0.021)\end{array}$ & $\begin{array}{l}0.045 \\
(0.025)\end{array}$ & $\begin{array}{l}0.084^{*} \\
(0.010)\end{array}$ & $\begin{array}{l}-0.039 * \\
(0.011)\end{array}$ \\
\hline Children (18 or younger) & $\begin{array}{l}-0.023 \\
(0.016)\end{array}$ & $\begin{array}{c}0.017 \\
(0.020)\end{array}$ & $\begin{array}{c}0.000 \\
(0.029)\end{array}$ & $\begin{array}{l}-0.008 \\
(0.054)\end{array}$ & $\begin{array}{l}-0.066 \\
(0.065)\end{array}$ & $\begin{array}{c}0.005 \\
(0.026)\end{array}$ & $\begin{array}{l}-0.001 \\
(0.026)\end{array}$ \\
\hline Education level (ref: NVQ level & and above & & & & & & \\
\hline NVQ level 3 & $\begin{array}{l}0.062^{*} \\
(0.019)\end{array}$ & $\begin{array}{c}0.004 \\
(0.023)\end{array}$ & $\begin{array}{c}0.011 \\
(0.033)\end{array}$ & $\begin{array}{l}-0.085 \\
(0.070)\end{array}$ & $\begin{array}{c}-0.133 \\
(0.083)\end{array}$ & $\begin{array}{l}-0.003 \\
(0.030)\end{array}$ & $\begin{array}{c}-0.071+ \\
(0.029)\end{array}$ \\
\hline NVQ level 2 and below & $\begin{array}{l}0.081^{*} \\
(0.019)\end{array}$ & $\begin{array}{c}0.007 \\
(0.023)\end{array}$ & $\begin{array}{l}-0.025 \\
(0.033)\end{array}$ & $\begin{array}{l}-0.051 \\
(0.056)\end{array}$ & $\begin{array}{l}-0.089 \\
(0.066)\end{array}$ & $\begin{array}{c}0.039 \\
(0.030)\end{array}$ & $\begin{array}{l}-0.044 \\
(0.029)\end{array}$ \\
\hline Other qualifications & $\begin{array}{l}0.089^{*} \\
(0.023)\end{array}$ & $\begin{array}{l}-0.012 \\
(0.028)\end{array}$ & $\begin{array}{c}0.028 \\
(0.039)\end{array}$ & $\begin{array}{c}-0.215+ \\
(0.088)\end{array}$ & $\begin{array}{c}-0.369 * \\
(0.114)\end{array}$ & $\begin{array}{c}0.006 \\
(0.036)\end{array}$ & $\begin{array}{c}-0.087+ \\
(0.036)\end{array}$ \\
\hline No qualifications & $\begin{array}{c}0.027 \\
(0.024)\end{array}$ & $\begin{array}{c}-0.143^{*} \\
(0.032)\end{array}$ & $\begin{array}{c}-0.165^{*} \\
(0.045)\end{array}$ & $\begin{array}{c}-0.314 * \\
(0.102)\end{array}$ & $\begin{array}{c}-0.265+ \\
(0.116)\end{array}$ & $\begin{array}{c}-0.062 \\
(0.038)\end{array}$ & $\begin{array}{c}-0.428^{*} \\
(0.047)\end{array}$ \\
\hline
\end{tabular}




\begin{tabular}{|c|c|c|c|c|c|c|c|}
\hline No spouse information & $\begin{array}{c}-0.148^{*} \\
(0.026)\end{array}$ & $\begin{array}{c}-0.114 * \\
(0.034)\end{array}$ & $\begin{array}{c}-0.036 \\
(0.046)\end{array}$ & $\begin{array}{c}-0.249+ \\
(0.103)\end{array}$ & $\begin{array}{c}-0.314^{*} \\
(0.117)\end{array}$ & $\begin{array}{c}-0.117 * \\
(0.040)\end{array}$ & $\begin{array}{c}-0.101+ \\
(0.048)\end{array}$ \\
\hline \multirow[t]{2}{*}{ Spouse has job } & $-0.128^{*}$ & -0.009 & -0.028 & 0.013 & -0.032 & -0.081 & $0.302 *$ \\
\hline & $(0.033)$ & $(0.040)$ & $(0.058)$ & $(0.111)$ & $(0.129)$ & $(0.049)$ & $(0.054)$ \\
\hline \multirow[t]{2}{*}{ Hourly wages employed spouse } & -0.001 & 0.002 & -0.002 & 0.005 & 0.002 & 0.002 & -0.004 \\
\hline & $(0.002)$ & $(0.002)$ & $(0.004)$ & $(0.004)$ & $(0.005)$ & $(0.003)$ & $(0.003)$ \\
\hline \multirow[t]{2}{*}{ Spouse has part-time job } & 0.013 & 0.026 & 0.032 & 0.057 & 0.049 & 0.036 & 0.028 \\
\hline & $(0.022)$ & $(0.026)$ & $(0.039)$ & $(0.062)$ & $(0.076)$ & $(0.034)$ & $(0.031)$ \\
\hline \multirow[t]{2}{*}{ Spouse has temporary job } & $-0.137^{*}$ & $-0.141^{*}$ & -0.071 & -0.116 & -0.225 & -0.067 & $-0.150+$ \\
\hline & $(0.043)$ & $(0.050)$ & $(0.073)$ & $(0.132)$ & $(0.175)$ & $(0.064)$ & $(0.059)$ \\
\hline Imputed values & no & yes & no & yes & yes & yes & yes \\
\hline Log likelihood (selection model) & -17946 & -12470 & -5522 & -1613 & -1087 & -8085 & -7985 \\
\hline Observations & 55,057 & 52,641 & 50,164 & 14,561 & 14,394 & 51,074 & 50,935 \\
\hline
\end{tabular}

Coefficients of the selection equation; dependent variable $=1$ if job seeker entered a (new) job by the subsequent quarter, and $=0$ otherwise; standard errors in parenthesis .

Other explanatory variables: dummies for government office region, year and quarter and a dummy for the recession.

+ Significant at $5 \%, *$ Significant at $1 \%$. Standard errors in parenthesis. 
Table A2: Quality of the job found by unemployed and employed job seekers

\begin{tabular}{|c|c|c|c|c|}
\hline Characteristics of accepted job & $(1)$ & $(2)$ & $(3)$ & (4) \\
\hline \multirow[t]{2}{*}{ Wage (£ per hour) } & $-0.004 *$ & $-0.001 *$ & $-0.011^{*}$ & $-0.009 *$ \\
\hline & $(0.001)$ & $(0.000)$ & $(0.001)$ & $(0.002)$ \\
\hline \multirow[t]{2}{*}{ Temporary } & $0.042 *$ & $0.011^{*}$ & $0.126^{*}$ & $0.144^{*}$ \\
\hline & $(0.007)$ & $(0.003)$ & $(0.019)$ & $(0.030)$ \\
\hline \multirow[t]{2}{*}{ Working hrs same as sought } & $-0.035^{*}$ & $-0.010^{*}$ & $-0.093^{*}$ & $-0.101+$ \\
\hline & $(0.009)$ & $(0.003)$ & $(0.033)$ & $(0.050)$ \\
\hline \multirow[t]{2}{*}{ NVQ level 3} & $0.015+$ & 0.002 & & \\
\hline & $(0.007)$ & $(0.003)$ & & \\
\hline \multirow[t]{2}{*}{ NVQ level 2 and below } & 0.010 & 0.001 & & \\
\hline & $(0.007)$ & $(0.003)$ & & \\
\hline \multirow[t]{2}{*}{ Other qualifications } & $0.017+$ & 0.005 & & \\
\hline & $(0.008)$ & $(0.003)$ & & \\
\hline \multirow[t]{2}{*}{ No qualifications } & $0.064^{*}$ & $0.013^{*}$ & & \\
\hline & $(0.010)$ & $(0.004)$ & & \\
\hline \multirow[t]{2}{*}{ Recession } & $0.065^{*}$ & $0.015^{*}$ & & \\
\hline & $(0.010)$ & $(0.004)$ & & \\
\hline Imputed values & yes & no & yes & no \\
\hline Log likelihood (full model) & -14980 & -6363 & -6250 & -3102 \\
\hline LR test of indep. eqns. $($ rho $=0)$ & $138.85^{*}$ & $90.53 *$ & $31.97 *$ & $7.46^{*}$ \\
\hline Observations & 3,749 & 1,272 & 3,749 & 1,272 \\
\hline \multicolumn{5}{|l|}{ First Stage (coefficients) } \\
\hline \multicolumn{5}{|c|}{ Search method (ref: job centres, career offices etc.): } \\
\hline \multirow[t]{2}{*}{ Ads in newspapers } & $-0.095^{*}$ & $-0.124 *$ & -0.077 & $-0.120+$ \\
\hline & $(0.020)$ & $(0.027)$ & $(0.039)$ & $(0.049)$ \\
\hline \multirow[t]{2}{*}{ Direct approach employers } & -0.056 & $-0.119 *$ & -0.126 & $-0.176+$ \\
\hline & $(0.032)$ & $(0.044)$ & $(0.066)$ & $(0.083)$ \\
\hline \multirow[t]{2}{*}{ Ask friends/relatives } & $-0.073+$ & $-0.093+$ & -0.077 & -0.090 \\
\hline & $(0.030)$ & $(0.041)$ & $(0.061)$ & $(0.077)$ \\
\hline \multirow[t]{2}{*}{ Do anything else } & $-0.119+$ & -0.146 & -0.050 & -0.124 \\
\hline & $(0.053)$ & $(0.077)$ & $(0.119)$ & $(0.156)$ \\
\hline \multirow{2}{*}{ No. search methods } & $0.141 *$ & $0.137 *$ & $0.174 *$ & $0.173 *$ \\
\hline & $(0.004)$ & $(0.006)$ & $(0.009)$ & $(0.011)$ \\
\hline \multirow{2}{*}{ Searching 3-12 months } & $-0.143^{*}$ & $-0.094 *$ & $0.493 *$ & $0.526^{*}$ \\
\hline & $(0.019)$ & $(0.026)$ & $(0.039)$ & $(0.050)$ \\
\hline \multirow[t]{2}{*}{ Searching $>12$ months } & $-0.452^{*}$ & $-0.362 *$ & $0.646^{*}$ & $0.661 *$ \\
\hline & $(0.023)$ & $(0.033)$ & $(0.046)$ & $(0.060)$ \\
\hline \multirow[t]{2}{*}{ Age (10 years) } & $0.019+$ & 0.008 & -0.007 & -0.022 \\
\hline & $(0.008)$ & $(0.011)$ & $(0.016)$ & $(0.020)$ \\
\hline \multirow[t]{2}{*}{ Children (18 or younger) } & 0.012 & -0.005 & -0.029 & -0.023 \\
\hline & $(0.020)$ & $(0.028)$ & $(0.040)$ & $(0.052)$ \\
\hline \multicolumn{5}{|c|}{ Education level (ref: NVQ level 4 and above) } \\
\hline \multirow[t]{2}{*}{ NVQ level 3} & & & 0.028 & 0.049 \\
\hline & & & $(0.046)$ & $(0.058)$ \\
\hline NVQ level 2 and below & & & 0.059 & -0.008 \\
\hline & & & $(0.045)$ & $(0.058)$ \\
\hline Other qualifications & & & 0.028 & 0.047 \\
\hline & & & $(0.055)$ & $(0.068)$ \\
\hline No qualifications & & & -0.073 & -0.129 \\
\hline & & & $(0.061)$ & $(0.079)$ \\
\hline Spouse information & & & & \\
\hline No spouse information & $-0.101 *$ & -0.027 & -0.053 & 0.042 \\
\hline
\end{tabular}




\begin{tabular}{lcccc} 
& $(0.033)$ & $(0.045)$ & $(0.070)$ & $(0.089)$ \\
Spouse has job & -0.008 & -0.019 & -0.024 & -0.015 \\
& $(0.039)$ & $(0.057)$ & $(0.086)$ & $(0.113)$ \\
Hourly wages employed spouse & 0.002 & -0.002 & -0.002 & -0.006 \\
& $(0.002)$ & $(0.004)$ & $(0.005)$ & $(0.007)$ \\
Spouse has part-time job & 0.025 & 0.028 & $0.164^{*}$ & $0.204^{*}$ \\
& $(0.026)$ & $(0.038)$ & $(0.052)$ & $(0.069)$ \\
Spouse has temporary job & $-0.139^{*}$ & -0.061 & $-0.258+$ & -0.251 \\
& $(0.050)$ & $(0.072)$ & $(0.105)$ & $(0.141)$ \\
Individual fixed effects & & & $6.084^{*}$ & $5.435^{*}$ \\
& & & $(0.083)$ & $(0.100)$ \\
Log likelihood (selection model) & -12591 & -5569 & -3764 & -2256 \\
Observations & 54,175 & 51,698 & 87,328 & 84,851 \\
\hline
\end{tabular}

Marginal effects of Heckman selection probit models; dependent variable $=1$ if person hired in the job was unemployed, and $=0$ if it was an employed job seeker. Selection equation other explanatory variables: dummies for government office region, year, quarter and a dummy for the recession (in columns 3 and 4).

+ Significant at $5 \%, *$ Significant at $1 \%$. Standard errors in parenthesis. 